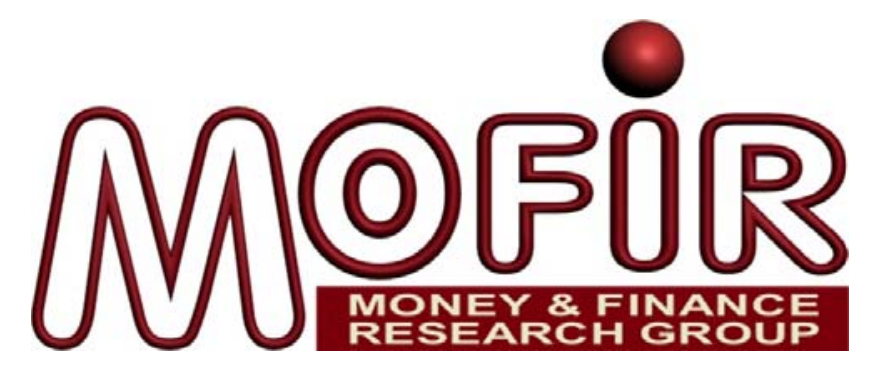

\title{
FDI AND GROWTH: WHAT CROSS-COUNTRY INDUSTRY DATA SAY
}

\author{
MARIA CIPOLLINA \\ Università degli Studi del Molise \\ GIORGIA GIOVANNETTI \\ Universtà di Firenze \\ European University Institute \\ FILOMENA PiETROVITO \\ Università degli Studi del Molise \\ AlBERTO FranCO POZZOLO \\ Università degli Studi del Molise \\ Centro Studi Luca d'Agliano \\ MoFiR
}

MoFiR working paper $n^{\circ} 51$

May 2011 


\title{
FDI and growth: What cross-country industry data say*
}

\author{
Maria Cipollina \\ (Università degli Studi del Molise) \\ Giorgia Giovannetti \\ (Università di Firenze and European University Institute) \\ Filomena Pietrovito \\ (Università degli Studi del Molise) \\ Alberto Franco Pozzolo \\ (Università degli Studi del Molise, Centro Studi Luca d'Agliano and MoFiR)
}

\begin{abstract}
$\underline{\text { Abstract }}$
The theoretical literature has discussed different channels through which foreign direct investments (FDI) promote host country's economic growth, but empirical analyses have so far been inconclusive. In this paper we provide evidence that FDI have a positive and statistically significant growth effect in recipient countries, using a panel of 14 manufacturing sectors for (a sample of) developed and developing countries over the period 1992 2004. Moreover, we find that this effect is stronger in capital intensive and in technologically advanced sectors, highlighting the importance of sector characteristics. We find that the growth enhancing effect comes primarily from an increase in total factor productivity (TFP) and from capital accumulation. FDI not only contribute to physical capital accumulation, but also generate positive technological spillovers. Our results are robust to the inclusion of other determinants of economic growth. We also address the issue of potential endogeneity and results are confirmed. Policy implications of our findings are important, especially for developing countries, where the growth enhancing promotion of foreign investment in capital intensive and technologically advanced sectors is at the heart of the debate.
\end{abstract}

JEL classification: F23; F36; F43; O16

Keywords: Foreign direct investment; Economic growth; Capital intensity, Technological progress; Patents; Total factor productivity

\footnotetext{
* We would like to thank Filippo Reganati and seminar participants at the Brown Bag Lunch Meeting at the Italian Treasury, at the $11^{\text {th }}$ European Trade Study Group Annual Conference, at the $25^{\text {th }}$ European Economic Association Annual Meeting, and at the $51^{\text {st }}$ Scientific meeting of the Società Italiana degli Economisti. Cipollina, Pietrovito and Pozzolo acknowledge financial support from the "New Issues in Agricultural, Food and Bio-energy Trade (AGFOODTRADE)" (Small and Medium-scale Focused Research Project, Grant Agreement no. 212036) research project funded by the European Commission. The views expressed in this paper are the sole responsibility of the authors and do not necessarily reflect those of the European Commission. Address for correspondence: Alberto Franco Pozzolo, Dipartimento di Scienze Economiche, Gestionali e Sociali, Università degli Studi del Molise, via de Sanctis, 86100, Campobasso, Italia. E-mails: cipollina@unimol.it; giorgia.giovannetti@unifi.it; filomena.pietrovito@unimol.it; pozzolo@unimol.it.
} 


\section{Introduction}

Foreign direct investments (FDI) increased substantially in the last decades. According to UNCTAD (2009), the stock of inward world FDI raised from a nominal value of US \$1,941 billion in 1990 to US $\$ 15,660$ billion in 2007. As a ratio of world GDP they more than trebled to slightly less than 30 per cent both in developed and developing countries. The bulk of FDI stocks is in services and manufacturing sectors (62 per cent and 28 per cent, respectively). Within manufacturing, the presence of foreign enterprises is stronger in chemicals ( 21 per cent), electrical and electronic equipments and food and beverages (10 per cent each).

Many analysts and policy makers see the recent surge in FDI as a positive aspect of globalization, for their potentially growth enhancing effects in countries at different level of development. In less developed countries, FDI may trigger capital accumulation, possibly enhancing future industrialization, while in developed countries, FDI represent the main way through which technologies are imported and new production and working practices introduced. Some analysts, however, stress that foreign investors while typically exploiting favorable local conditions, such as lower labor costs and looser regulations, have very limited effects on the host countries' economic welfare.

Despite a large number of theoretical models highlighting the channels through which FDI can enhance growth, the empirical literature has so far failed to provide clear-cut evidence: the "empirical evidence for FDI generating positive effects for host countries is ambiguous at both micro and macro levels" (Alfaro et al., 2009), to quote one among many of a similar spirit. Hanson (2001), in a detailed survey, argues that there is weak evidence that FDI generate positive spillovers for host countries. In a (micro-level) literature review on spillovers from foreign to domestically owned firms, Görg and Greenaway (2004) conclude that the effects are mostly negative.

From a policy perspective, the lack of robust empirical evidence is particularly disturbing. If FDI could be credibly shown to have a positive impact on economic growth, this would weaken the arguments for the still large (explicit and implicit) restrictions to which they are subject.

This paper aims at contributing to this debate. We provide evidence of positive and statistically significant effects of FDI on the rate of growth of industries in recipient countries, and we show that this effect is stronger in capital intensive sectors and in sectors with higher levels of technological development. We believe that our findings also provide some support to the new endogenous growth literature emphasizing the importance of innovation efforts by profit-seeking firms as a major engine of technological progress and productivity growth (Bottazzi and Peri, 2005; Coe et al., 2009). Our empirical results are consistent with the three major explanations of why FDI may potentially enhance the growth rate of value added at industry level in the host country: 
technological innovation, labor accumulation and capital accumulation (Aitken and Harrison, 1999; Keller and Yeaple, 2009; Alfaro et al., 2009).

Our analysis is based on a panel of 14 industries for up to 22 developed and developing countries between 1992 and 2004. We estimate the effect of FDI on host countries' growth including in the specification a set of country, sector and time dummies to account for all timeinvariant unobserved characteristics. Moreover, using data at industry level we (i) take into account potential heterogeneity in the effect of FDI on growth depending on sector characteristics and (ii) better evaluate the channels through which FDI may influence economic growth.

We believe that our contribution improves the existing literature on a number of dimensions. First, in the same vein of (few) ${ }^{1}$ earlier studies (Alfaro, 2003; Alfaro and Charlton, 2007), we analyze the impact of FDI on growth by using data at the level of industrial sector. We however innovate by considering, instead of inflows, a stock measure of FDI, less influenced by shorter term variability, and normalized over the value of total capital in each sector and country. We believe that the stock is a better measure of the foreign impact on the local economy, since flows could, in principle, be zero even in situations where foreign investors already own a country's entire industrial system. Moreover, foreign investment flows are more likely to be driven by the economic conditions in the host countries, possibly inducing endogeneity.

Second, we analyze the different impact of FDI according to sectors characteristics and, in particular, to capital intensity and technological level, finding that the effect on growth is much stronger in capital intensive and in high-tech industries. To the best of our knowledge, this is the first attempt to distinguish the effect of FDI on growth according to the sectors' capital intensity.

Third, to identify the main channels through which FDI enhance economic growth, we use growth in total factor productivity (TFP), capital and labor as dependent variables. Our evidence supports the view that a large part of the positive effect of FDI on sector growth is due to an increase in TFP and in capital accumulation in all manufacturing sectors. ${ }^{2}$

The rest of the paper is organized as follows. The next section briefly reviews the relevant empirical literature. Section 3 describes the empirical methodology. Section 4 describes the data and presents some descriptive statistics. Section 5 discusses the econometric results. Section 6 draws some conclusions.

\footnotetext{
${ }^{1}$ There are few studies of FDI at sector level due to scarce and often unreliable data availability.

${ }^{2}$ Alfaro and Charlton (2007) perform a similar analysis, but they analyze only the technological channel without taking into account factors accumulation. On the other hand, Alfaro et al. (2009) analyze both technological and factor accumulation channels, as we do, but use aggregate data.
} 


\section{Related literature}

It is widely believed that the presence of foreign firms can have an impact on recipient countries well beyond the effect of the increase in its total capital, by generating large positive externalities, possibly improving the country's technology, with positive effects on aggregate productivity and growth. ${ }^{3}$ This channel has been analyzed in detail in a number of papers, mainly in line with the R\&D endogenous growth models. For example, Grossman and Helpman (1991, chapter 7) and Baldwin et al. (2005) show how multinational firms and FDI can promote knowledge spillovers enhancing growth. Such spillovers can take place through many different channels. Kokko (1992) suggests that technological differences between multinationals and domestic firms can favor a process of contagion and imitation through direct contacts, as in Findlay (1978). Multinationals are also likely to increase the demand for locally produced goods and services, with domestic firms benefiting from economies of scale and scope (Rodriguez-Clare, 1996). Further, they can increase competition in the foreign country, favoring the selection of the most efficient local firms. Finally, workers trained within a multinational corporation can be hired by domestic producers, transferring part of their superior technological and managerial skills. ${ }^{4}$ Clearly, the impact of these channels is closely linked to the strength of foreign affiliates and local firms economic links and to the specific nature of the relationship, for instance being suppliers of raw materials and intermediate products (Lall, 1980; Rodriguez-Clare, 1996; Markusen and Venables, 1999; Lin and Saggi, 2007).

These rich theoretical analyses have prompted a vast empirical literature, broadly classified into three major groups, depending on whether they use cross-country, sectoral, firm or plant level data. Despite the number of studies, the empirical evidence in inconclusive.

Works based on simple cross-country analyses have in general failed to find a positive effect of FDI on growth. Choe (2003), for example, uses a panel VAR model to explore the interaction between FDI and economic growth in eighty countries in the period 1971-1995, finding evidence that FDI Granger cause economic growth, but the opposite is also true and it is economically and statistically stronger. Carkovic and Levine (2005), using GMM to study a large sample of countries between 1960 and 1995, find no robust causal effect between foreign investment inflows and economic growth. Similarly, Alfaro et al. (2009) find no significant evidence of a positive impact of FDI on growth, excluding some positive effect for financially developed countries.

A number of authors suggested that the weak evidence of positive effects of FDI on growth obtained from standard cross-country regressions depends on the fact that these empirical models do not account for the absorptive capacity of recipient countries, i.e., the extent to which they are

\footnotetext{
${ }^{3}$ For instance, Castellani and Zanfei (2006) focus on the effects of multinationals on innovation and productivity.

${ }^{4}$ See for example, Findlay (1978), Mansfield and Romeo (1980), Blömstrom (1986), Kinoshita (1998) and Sjöholm (1999).
} 
able to adopt and implement the new available technologies. As convincingly argued by De Mello (1999) and Blömstrom and Kokko (2003), the positive spillovers from the presence of foreign investors are likely to depend on the level of human capital, on the development of financial markets and on the quality of recipient countries' institutional framework. A set of papers has stressed the role of human capital. Focusing on developing countries, Borensztein et al. (1998) show that foreign investment inflows have a positive effect on the recipient country's rate of growth only if the level of human capital is above a given threshold. Analyzing data of US multinationals, $\mathrm{Xu}$ (2000) argues that most less developed countries do not reach such a threshold. Studying a panel of 84 countries between 1970 and 1999, Li and Liu (2005) confirm that human capital is an important catalyst for FDI to have a positive effect on growth, also for more advanced economies. However, they also show that FDI can have a negative effect on growth when the technology gap between the investing and the recipient countries is too wide. ${ }^{5}$ Narula and Marin (2003), using firm level data from Argentina, confirm that only firms with high absorptive capacity are able to exploit positive spillover generated by FDI. ${ }^{6}$

In a seminal contribution, Alfaro et al. (2004) show that the positive FDI effect on growth is linked to the level of development of financial markets. ${ }^{7}$ Indeed, FDI spillovers benefit the host by favouring a broad restructuring of the local industrial system, possible if there are no financial constraints. In line with this result, Alfaro et al. (2009) show that "countries with well-developed financial markets gain significantly from FDI via TFP improvements". Hermes and Lensink (2003) and Durham (2004) provide additional evidence supporting the role of financial development, focusing respectively on the role of financial intermediaries and financial markets. ${ }^{8}$

In addition, some authors highlighted the importance of host countries' institutional environment, such as political stability and degree of urbanization (Hsiao and Shen, 2003), risk of expropriation (Alfaro et al., 2004), institutional quality, including corruption (Durham, 2004), economic stability and freedom (Bengoa and Sanches-Robles, 2003).

A second strand of literature focused on sector data, finding much stronger evidence of positive effects of FDI on growth. Earlier studies provide generic evidence that FDI generate positive spillovers for some sectors of the hosting countries. ${ }^{9}$ Blömstrom (1986) shows that stronger

\footnotetext{
${ }^{5}$ In contrast with these findings, Carkovic and Levine (2005) find no positive effect of FDI on growth even when their effect is shaped by the level of human capital.

${ }^{6}$ On a partially related ground, Alfaro et al. (2010) show that FDI have a stronger growth effect when goods produced by domestic and multinational firms are substitutes, rather than complements.

${ }^{7}$ See also Beck et al. (2000a and 2000b) for the relevance of financial development for economic growth.

${ }^{8}$ Recently, Alfaro et al. (2010) formalize a mechanism that emphasizes the role of local financial markets in enabling FDI to promote growth through backward linkages. Using realistic parameter values, they quantify the response of growth to FDI and show that an increase in the share of FDI leads to higher additional growth in financially developed economies relative to financially under-developed ones.

${ }^{9}$ See Caves (1974) for Australia, Globerman (1979) for Canada, Blömstrom and Persson (1983), Blömstrom and Wolff (1994) for Mexico and Sjöholm (1999) for Indonesia.
} 
competitive pressure triggers positive results. In more recent work, Haskel et al. (2006) show a positive and significant correlation between sector TFP and the foreign-affiliate share of activity in UK, and Keller and Yeaple (2009) find that international technology spillovers to US-owned manufacturing firms via FDI lead to significant productivity gains for domestic firms, especially in the relatively high-tech industries. Görg and Greenaway (2004) criticized these studies because of the likely presence of endogeneity: a positive relationship between FDI and productivity can be found if foreign investment did not cause but were attracted by higher productivity. However, Alfaro and Charlton (2007) tackle the endogeneity issue studying foreign investment inflows in a large sample of countries and industries using as instruments for FDI a dummy for the industry sectors targeted for foreign investment promotion and the lagged value of FDI. Their results confirm a positive and significant effect of FDI on sector growth, stronger for industries with higher skill requirements and more reliant on external capital.

Finally, a number of authors look for positive spillover effects of FDI using firm and plant level data. In a seminal contribution exploiting information on Venezuelan plants, Aitken and Harrison (1999) find no evidence of intra-industry spillovers from foreign firms on domestic firms. Their result is confirmed by Alfaro and Rodríguez-Clare (2004) who, surveying a number of papers using plant-level data, highlight the weak evidence of positive externalities from multinationals to local firms in the same sector (horizontal externalities). Indeed, many studies find evidence of negative horizontal externalities arising from multinational activity and of weak positive externalities from multinationals to local firms in upstream industries (vertical externalities). Even the most recent literature using firm level data has been unable to reach unambiguous results: Javorcik (2004) and Blalock and Gertler (2003) find no clear evidence in favor of neither intraindustry spillovers, nor forward linkages. However, these results contrast with those of Haskel et. al. (2006), Branstetter (2006) and Keller and Yeaple (2009), who find economically and statistically significant evidence that FDI increase knowledge spillovers both from and to the investing firms.

\section{The empirical framework}

Our paper studies the causal effect of FDI on the recipient country's economic growth using sector level data. Our baseline empirical model is the following: 


$$
\begin{aligned}
& V A \_ \text {growth }_{i j t}=\mathrm{a}_{0}+\mathrm{a}_{1} \ln (F D I / K)_{i j t-5}+\mathrm{a}_{2} \text { VA_Share } e_{i j t-5}+\mathrm{a}_{3} \ln (V A)_{i j t-5}+\mathrm{a}_{4} S_{\text {Sec_char }} \text { Cht } 5+ \\
& +\mathrm{a}_{5} \text { Cou_char }{ }_{j t-5}+\mathrm{a}_{6} \text { Time_dum }_{t}+\mathrm{a}_{7} \text { Cou_dum } m_{j}+\mathrm{a}_{8} S e c \_d u m_{i}+\varepsilon_{i j t}
\end{aligned}
$$

where: VA_growth $h_{i j t}$ is the average rate of growth of value added in sector $i$ of country $j$ in the five years ending at time $t ; \ln (F D I / K)_{i j t-5}$ is the ratio of the stock of FDI to the total stock of capital in sector $i$ of country $j$ at time $t-5 ;{ }^{10}$ VA_Share $e_{i j t-5}$ is the share of value added of sector $i$ of country $j$ at time $t-5$ over the total value added of the country (to account for sector size); $\ln V A_{i j t-5}$ is the initial level of value added of sector $i$ of country $j$ at time $t-5$ (to account for possible convergence effects); Sec_char $i t-5$ and $C o u \_c h a r r_{j-5}$ are time-varying specific characteristics of sector $i$ and country $j$ at time $t$-5, when included; Time_dum $m_{t}$ are time dummies; Cou_dum $m_{j}$ are country dummies; Sec_dum are sector dummies and $\varepsilon_{i j t}$ is a standard error term. ${ }^{11}$

In order to better exploit the information in our data, regressions are based on all overlapping available five years rates of growth of value added, as in Bekaert et al. (2007). As robustness checks, we also estimate the baseline specification using as dependent variable the growth rate of value added over non-overlapping five years, and over a longer period of ten overlapping years.

On the basis of the theoretical models mentioned above, we expect $a_{1}$ to be positive and statistically significant. The strength of this specification is that it allows for the estimation of the effects of FDI on sector growth, controlling for all country and sector invariant unobserved characteristics. The potential omission of relevant variables is accounted for, because their effect would not been captured in our specification only if it came from features that are at the same time country and sector specific.

We include in our empirical specification a set of time varying sector and country specific characteristics. In line with the existing literature, to control for country specific characteristics, we consider institutional environment, financial development and human capital. At the sector level, we split the sample according to the level of capital and technological intensity, to see whether the effect of FDI is different between labor intensive and capital intensive sectors and between HighMiddle- and Low-tech sectors. The choice of the proxy for the unobservable technical change in this case is not neutral. Different proxies have been adopted in empirical models, ranging from measures of the inputs involved into the innovation process, such as R\&D expenditures (Coe and Helpman, 1995; Engelbrecht, 1997; Coe et al., 2009), to output measures such as the number of inventions which have been patented (Acs and Audretsch, 1989; Acs et al., 1991 and 2002), to institutional characteristics such as the degree of patent protection (Bottazzi and Peri, 2003; Coe et

\footnotetext{
${ }^{10}$ The stock of foreign investment is normalized by the total capital stock in each sector and country because foreign firms are likely to have a different effect depending on the size of the sector where they operate (e.g., an identical car manufacturing plant is likely to impact substantially on the value added of the Hungarian car industry, but much less on that of the United States).

${ }^{11}$ Our specification is rather common in the growth literature (e.g., Rajan e Zingales, 1998; Alfaro and Charlton, 2007).
} 
al., 2009), to direct measures of innovative output originated in the work of Pavitt et al. (1987) and Edwards and Gordon (1984). In what follows, we use the number of patents. ${ }^{12}$

Finally, since in principles FDI can contribute to growth via factors accumulation and via improvements in TFP, to better identify what is the main channel (if any) at work in our empirical model, we also estimate additional specifications using TFP, labor and capital growth as the dependent variables.

\section{Data and summary statistics}

Our data set is built around information on 14 manufacturing sectors for up to 22 developed and developing counties over the period 1992-2004. ${ }^{13}$ Table A in the Appendix provides a synthetic description of all sector and country variables used in our empirical analysis and of their sources.

Information on our key dependent variable, the value added at the sector level for a large sample of developed and developing countries, and on aggregate sector investment is from the Industrial Statistics of the United Nations Industrial Development Organization (UNIDO; Indstat4 2008, Revisions 2 and 3). Data, originally expressed in nominal US dollars, have been deflated using the price level of investment goods (and, when not available, of consumption goods) from version 6.2 of the Penn World Tables, base year 2000 (Heston et al., 2006).

Information on FDI at the sector level comes from the United Nations Conference on Trade And Development (UNCTAD) database, which collects yearly values of inward stocks of FDI for 41 developed and developing countries, starting from 1970, although with many gaps. Since data on value added are classified according to the International Standard Industrial Classification (ISIC) of manufacturing activities and FDI data follow a different classification, we reconciled them according to the schemes presented in Tables $\mathrm{C}$ and $\mathrm{D}$ in the Appendix.

FDI are defined as the stock of investment required to acquire a lasting management interest in an enterprise operating in an economy other than that of the investor. They include equity capital, reinvestment of earnings, other long-term capital and short-term capital. Each sector's capital stock has been estimated from information on investment flow using the inventory method (Bernanke and Gurkaynak, 2002; Isaksson, 2009). We adopt the following procedure: (i) for each country, we calculate each sector's share of investment using flow information for the first five years of data available; (ii) we use investment shares to divide information on each country's total capital provided by UNIDO's World Productivity Database across sectors; (iii) we use the estimates of the country and sector specific initial stock of capital obtained as described above as the starting point

\footnotetext{
${ }^{12}$ For a review of the patent literature, see Griliches (1990).

${ }^{13}$ The countries included in our largest sample are: Australia, Austria, Bolivia, Canada, Denmark, Finland, France, Germany, Hong Kong, Indonesia, Italy, Netherlands, Peru, Philippines, Portugal, Korea, Singapore, Sweden, Switzerland, UK, US and Venezuela.
} 
to apply the inventory method, i.e., adding each year's value of real term investment and applying a sector specific rate of depreciation to account for obsolescence.

The additional country- and industry-specific variables used in the empirical analysis are from standard sources. Institutional quality and stability are proxied by a measure of the control of corruption, measuring external investors' perception of the extent to which public powers are used for private gains ${ }^{14}$. Financial development is measured by the ratio of credit to the private sector granted by deposit money banks and other financial institutions to GDP (Beck and Levine, 2002 and 2004; Beck, Demirguc-Kunt and Maksimovic, 2008) ${ }^{15}$. The industry skill intensity is the ratio of high skilled workers to total employment (see Carlin and Mayer, 2003). ${ }^{16}$ Technological intensity is proxied by the total number of utility patents produced worldwide in each sector and granted by the US Patent Office. ${ }^{17}$ Finally, TFP at sectoral level has been computed from information on the number of workers and output per-capita from UNIDO's Industrial Statistics and using our estimates of total capital. We used a constant return to scale Cobb-Douglas production function: $T F P=Y /\left(K^{a} L^{1-a}\right)$, where $Y$ is the sector's value added, $K$ is the stock of capital at the sector level and $L$ is the number of employees in the sector, assuming a capital share of 1/3 and a labor share of $2 / 3$. Table 1 presents the descriptive statistics, showing a significant variability over the sample. ${ }^{18}$

\section{Empirical results}

\subsection{FDI and value added growth}

The results of the baseline specification are reported in Table 2. Panel 1 presents the estimates excluding year, country and sector dummies, and without time varying controls, showing that the ratio of FDI stock to total capital stock at the beginning of the period has a positive effect on the average rate of growth in each sector in the following five years, with a coefficient of 0.031 , statistically significant at the 5 per cent level.

\footnotetext{
${ }^{14}$ Data are from the World Bank's Worldwide Governance Indicators (WGI).

${ }^{15}$ This information is from the World Bank Database on Financial Development and Financial Structure.

16 Occupational data are based on the new version of the International Labor Office's International Standard Classification of Occupations, ISCO 88. Following Alfaro and Charlton (2007), categories and subcategories are defined as: white-collar high-skill includes legislators, senior officials, and managers (group 1), professionals (group 2), technicians and associate professionals (group 3), white-collar low-skill includes clerks and service workers (group 4) and shop and sales workers (group 5), blue-collar high-skill includes skilled agricultural and fishery workers (group 6) and craft and related trade workers (group 7), blue-collar low-skill includes plant and machine operators and assemblers (group 8) and elementary occupations (group 9).

${ }^{17}$ Data are from the National Bureau of Economic Research database. Since the original data on patents are classified according to the US Patent Classification, we combined them with information on value added adopting the correspondence scheme between the US Patent Classification and the International Patent Classification and between the latter and the ISIC3 provided by Johnson (2002).

${ }^{18}$ For instance, the five year real value added growth at the sector level, our main dependent variable, is on average 0.181 , but its standard deviation is 0.673 , with values ranging from -5.824 to 4.562 . The ratio of FDI to total capital stock is on average 0.141 , with a standard deviation of 0.558 . Other control variables also show a very high crosscountry variability.
} 
Panels 2 to 5 present the estimates obtained including different combinations of time, country and sector dummies, to control for the effects of potential unobservable characteristics that might bias our estimates. Our model is robust: the estimated coefficients on the ratio of FDI stock to capital stock are always positive and statistically significant. Moreover, with the inclusion of additional fixed effects, the estimated coefficient of our variable of interest becomes progressively larger. In our preferred specification, including all sets of dummies (Panel 5), the coefficient of the share of FDI over total capital at the beginning of the period is 0.054 , and it is statistically significant at the 5 per cent level.

This effect is also economically significant, since an increase of one standard deviation in the ratio of the FDI stock to total capital (i.e. an increase of 0.558 ) implies a rise of 0.030 in the rate of growth rate, about 17 per cent of the average.

Table 3 presents the results obtained including also time-varying country specific measures of the degree of control of corruption, of the development of financial markets and of the share of skilled workers. With the only exception of the specification reported in Panel 1, where the degree of control of corruption has a positive and statistically significant effect, additional controls are not statistically significant. This is most likely due to the fact that these measures display limited within country time variability, and their larger cross-country variance is accounted for by the inclusion of country dummies. Reassuringly, in all cases the numerical value of the coefficient of the FDI share over total capital is still positive and statistically significant, confirming our previous findings.

\subsection{Labor, capital and technological intensity}

It has been argued by a large strand of theoretical and empirical literature that the impact of foreign investment may be substantially different depending on the characteristics of the industrial sector in the host country. For example, FDI driven by a search for lower wages and in labor intensive sectors have probably lower effects on growth than those in capital intensive sectors, where productivity differences between domestic and foreign firms may be much starker.

Part of the literature on the determinants of FDI has also stressed that profit maximizing firms will successfully locate part of their activities in a foreign country only if they have some advantage with respect to local producers (see, e.g., Markusen, 1995). Since the positive effects of FDI for the recipient economy typically come from technological spillovers, the most likely kind of advantage of foreign firms with respect to local competitors is on technological grounds. According to this logic, the effects of FDI should be stronger in sectors where local firms have a wider technological gap with respect to foreign competitors. Since technologies spread slowly from advanced to developing countries, we assume that the technological gap is likely to be larger in technologically advanced sectors, measured by the intensity of their patent production. An alternative hypothesis, 
emphasizing the role of catching-up technologies, is that the benefit obtained from FDI might be higher in sectors with low technological level.

To study the effect of capital and technological intensity on the relationship between FDI and growth, we split our sample according to two measures. First, we focus on capital intensity and split the sample according to the median level of the capital to labor ratio in each sector. ${ }^{19}$ Labor intensive sectors are those with a ratio below the sample median, whereas capital intensive sectors are those with a ratio above the sample median. Second, we focus on technological intensity and split the sample in three groups, depending on each sector's degree of technological intensity, measured by the total number of patents that has been granted to each sector by the US patent office to inventors all over the world. In all cases, estimates are conducted using our preferred econometric specification, including year, country and sector dummies.

The results are presented in Table 4. Panel 1 shows that for labor intensive sectors FDI have positive but statistically insignificant effect on growth. On the contrary, Panel 2 shows that FDI in capital intensive sectors have a positive and significant effect on growth, with a coefficient of 0.077 (statistically significant at the 5 per cent level). An increase of one standard deviation in the ratio of the FDI stock to total capital (i.e. an increase of 0.558) in capital intensive sectors implies a rise in the growth rate of 0.043 , that is 24 per cent of the average rate of growth. These results support the view that foreign investment in labor intensive sectors are likely to be less beneficial for the host countries, since they do not allow spreading new technologies and production processes.

The results obtained splitting the sample according to the degree of technological intensity, reported in Panels 3-5, provide additional evidence consistent with the view that FDI aimed only at profiting from low labor costs have no significant effects on value added growth in the host countries. The effect of FDI on value added growth is positive but statistically insignificant in Lowtech sectors (Panel 3), positive and statistically significant in more technologically advanced sectors. Interestingly, the coefficient is larger for Middle-tech sectors $(0.101$, statistically significant at the 5 per cent level) than for High-tech sectors $(0.059,10$ per cent level). Indeed, some countries are unable to reap all the benefits of the spillovers from very advanced firms, because the gap from the technological frontier is too large. In the case of Middle-tech sectors FDI benefits can be substantial, since an increase of one standard deviation in the ratio of the FDI stock to total capital (0.558) implies a rise of 0.056 in the growth rate, nearly one third of the average rate of value added growth.

\footnotetext{
${ }^{19}$ Consistent with our expectations, among others, textile and wood are classified as labor intensive sectors while plastic products and chemicals, paper and paper products and electric machinery are capital intensive sectors.
} 


\subsection{Total factor productivity, labor and capital growth}

Our results show that FDI have a positive (and robust) effect on host country growth, the more so in capital intensive and in Middle-tech sectors. We believe that this is an important finding, also for policy prescriptions. Hence, we go a step further in understanding the mechanism driving this result, and we investigate whether it is due to factors accumulation and/or to an increase in TFP, as suggested, among others, by Keller and Yeaple (2009), and Alfaro et al. (2009).

Table 5 presents results obtained using in turn TFP, labor and capital inputs as dependent variable. Panel 1 shows that, in line with the view that spillovers affect sector productivity, FDI have a positive and significant effect on the rate of growth of TFP, with a coefficient of 0.046 (statistically significant at the 5 per cent level). The economic impact is substantial, with an increase of one standard deviation in the ratio of the stock of FDI to that of total capital (0.558) causing a rise of 0.026 in the growth rate of value added, 37 per cent of the average rate of TFP growth. Panels 2 and 3 report a significant effect of FDI on total capital growth, but not on labor growth. In all three cases the coefficient of the level of the dependent variable at the beginning of the period is negative, consistent with the convergence hypothesis. ${ }^{20}$

\subsection{Endogeneity}

So far we did not tackle the endogeneity problem, which has been raised as a major concern in interpreting the evidence on the FDI-growth relationship. In principles, it is plausible that multinationals invest abroad in sectors expected to have higher growth rates in the near future. This reverse causality would lead to an overestimation of the effect of FDI on value added growth. Indeed, in our empirical specification we use FDI stocks rather than flows, which are more likely to be influenced by future growth prospects. Besides, our time, country and sector dummies control for a wide range of potential omitted factors, which might bias our results.

However, to check robustness of our results we re-estimate the model using lagged levels of the ratio of FDI to total capital as instruments for the level at the beginning of each five-years growth period, in line with Arellano and Bond (1991). Panels 1 to 4 of Table 6 report the results for respectively rates of growth, TFP, capital and labor using our preferred specification, which includes all set of dummies. The results confirm the previous findings. The coefficients of the ratio of FDI to total capital are positive and statistically significant for all variables, with the exception of the number of employees. This suggests that the positive effect of foreign investment on growth comes from a higher rate of capital accumulation and a faster increase in factor productivity. ${ }^{21}$

\footnotetext{
${ }^{20}$ Note that, in the case of capital, the coefficient, though negative is not statistically significant.

${ }^{21}$ In other regressions not reported for reason of space, but available on request, we obtained similar results using different instruments. More specifically, we used as instruments the one year lagged level of FDI over total capital, a
} 


\subsection{Robustness checks}

As mentioned above, in our estimates we use all overlapping five-year periods available in our data set, in line with Bekaert et al. (2007). While this procedure allows us to have a larger number of observations, it might cause some heteroskedasticity problems, not fully controlled by the use of a robust variance estimator. To further investigate the issue, we consider an additional specification using non-overlapping five-year periods. With this specification we only have 194 observations; hence, to economize on the degrees of freedom, we include in the model only the dummies that in a first stage regression showed a statistically significant coefficient. The results, reported in Panel 1 of Table 7, confirm the findings of the baseline specification.

As an additional robustness check we also estimate our original regression model using overlapping rates of growth calculated over a longer time span of ten years. Also this specification confirms our results. The coefficient of the ratio of the FDI stock to that of total capital is 0.131 , about twice as large as that estimated over the shorter time span of five years, and it is statistically significant at the 1 per cent level. ${ }^{22}$

Finally, since our measure of the relative incidence of FDI is based on an estimate of the capital stock not available for all sectors and countries in our initial sample, we also verify if our findings are confirmed using, as an alternative measure of the incidence of FDIs, the ratio of the stock of foreign FDI on each sector's value added. ${ }^{23}$ The estimates are in this case based on a sample of 1,453 observations, 683 more than in our baseline specification. Reassuringly, the results reported in Panels 3 to 5 confirm the findings of the baseline regression as well as those of the two robustness checks reported in Panels 1 and 2 of the same table. ${ }^{24}$

\subsection{A focus: Is the impact of FDI on growth the food processing industry different?}

Having assessed the positive and significant effect of FDI on growth of recipient countries, we now focus on the food processing industry. As argued by UNCTAD, transnational corporations established in downstream segments of host-country value chains (e.g. food processing and supermarkets) also invest in agricultural production and contract farming, thereby multiplying the

\footnotetext{
measure of capital openness and a measure of investor protection, as well as using all set of instruments at the same time.

${ }^{22}$ In some sectors of smaller countries, the ratio of FDI to total capital stock can be much higher than the median levels. In unreported regressions we have checked that our results are confirmed and strengthened when these observations are excluded from our estimation sample. Consistently, also estimates over the entire sample using robust regression techniques provide statistically stronger results.

${ }^{23}$ In unreported regressions, available upon request, we have checked that our results are robust to the exclusion of influencing observations showing high ratio of FDI to value added.

${ }^{24}$ While we are convinced that the normalization of the stock of FDI is an essential contribution of our empirical framework, for comparison with the results of Alfaro and Charlton (2007) we have also estimated our baseline specification using as a regressor the logarithm of the absolute level of FDI stocks. The results, not reported for space reasons, but available on request, confirm the positive effect of FDI on sector growth.
} 
actual size of their participation in the industry. In fact, after a rapid rate of growth in the early 2000s, foreign investment flows in the food and beverages industry alone (i.e. not including other downstream activities) exceeded \$40 billion in 2005-2007 (UNCTAD, 2009).

To investigate the specific relationship between FDI and growth in the processed food industry, we augment the basic regression with an interaction term between the level of FDI normalized by capital and a dummy for the food sector. Moreover, to verify if the mechanism driving the overall effect of FDI is the same also in the food processing industry, we analyze the effect of FDI on the different components of value added growth: TFP, labor and capital.

Our results show that FDI have the same effect on the rate of growth of value added, TFP and labor in the food processing industry as in all other sectors of economic activity. On the contrary, in the food sector foreign investment exert a significantly stronger effect on the rate of growth of total capital.

\section{Conclusion}

The ample number of empirical analysis on the determinants of economic growth after the publication of the seminal paper by Barro and Sala-i-Martin (1992), led at the time many authors to believe that it would be easy to show that FDI have a positive, economically relevant and statistically significant effect on the rate of growth of recipient countries. To the surprise of many and the disappointment of others, such sound and robust evidence has not been found. Indeed, the debate on FDI and growth has not yet been able to reach an unambiguous conclusion on the sign of the effect. In addition, most of the analyses that find the strongest evidence of a positive and significant effect are flawed by strong endogeneity problems.

In this paper we provide some new evidence supporting a positive impact of FDI on host countries' growth. Our empirical analysis, based on sector specific data for a reasonably large set of developed and developing countries, reveals a strong, robust, and economically and statistically significant effect of FDI on growth. Besides, our evidence is robust to controlling for potential endogeneity issues that might not be fully controlled by our rich set of time, sector and country dummies. The positive effect of FDI is stronger in more capital intensive and technologically advanced sectors of economic activity, and it comes primarily from an increase in TFP and capital accumulation growth. As an example, consider a case where the ratio of the FDI stock to total capital in Italy (0.013) reached the one of France (0.021), Italy would experience an increase in the growth rate of value added of 0.21 per cent in the whole sample, between 0.34 per cent and 0.54 per cent in capital intensive sectors and 0.42 per cent in high-tech sectors.

In view of ours and previous results in the literature, we can argue that the removal of implicit and explicit barriers limiting the access of foreign investors should stay high in the policy makers' 
agenda. Policies promoting the inflows of foreign investment can be a powerful tool for economic growth, especially if addressed towards the most technologically advanced sectors of economic activity. 


\section{References}

Acs, Z., Anselin, L., Varga, A. (2002), Patents and innovation counts as measures of regional production of new knowledge. Research Policy 31, 1069-1085.

Acs, Z., Audretsch, D. (1989), Patents as a measure of innovative activity. Kyklos 42, 171-180.

Acs, Z., Audretsch, D., Feldman, M. (1991), Real effects of academic research: comment. American Economic Review 81, 363-367.

Aitken, B. J., Harrison, A. (1999), Do domestic firms benefit from direct foreign investment? Evidence from Venezuela. American Economic Review 89, 605-618.

Alfaro, L. (2003), Foreign direct investment and growth. Does the sector matter?. Harvard University, Harvard Business School, Working Paper.

Alfaro, L., Chanda, A., Kalemli-Ozcan, S., Sayek, S. (2004), FDI and economic growth: the role of local financial markets. Journal of International Economics 64, 89-112.

Alfaro, L., Chanda, A., Kalemli-Ozcan, S., Sayek, S. (2010), Does foreign direct investment promote growth? Exploring the role of financial markets on linkages. Journal of Development Economics 91(2), 242-256.

Alfaro, L., Charlton, A. (2007), Growth and the quality of foreign direct investment: is all FDI equal?. CEP Discussion Papers dp0830, Centre for Economic Performance, LSE.

Alfaro, L., Kalemli-Ozcan, S., Sayek, S. (2009), FDI, productivity and financial development. The World Economy 32, 111-135.

Alfaro, L., Rodriguez-Clare, A. (2004), Multinationals and linkages: evidence from Latin America. Economia 4, 113-170.

Arellano, M., Bond., S. (1991), Some tests of specification for panel data: Monte Carlo evidence and an application to employment equations. The Review of Economic Studies 58, 277 - 297.

Baldwin, R., Braconier, H., Forslid, R. (2005), Multinationals, endogenous growth, and technological spillovers: theory and evidence. Review of International Economics 13, 945-963.

Barro, R. J., Sala-i-Martin, X. (1992), Convergence . Journal of Political Economy 100, 223-251.

Beck, T., Levine, R. (2002), Industry growth and capital allocation: Does having a market- or bank-based system matter?. Journal of Financial Economics 64, 147-180.

Beck, T., Demirguc-Kunt, A., Levine, R. (2000a), A new database on financial development and structure. World Bank Economic Review 14, 597-605.

Beck, T., Demirguc-Kunt, A., Maksimovic, V. (2008), Financing patterns around the world: Are small firms different?. Journal of Financial Economics 89, 467-487.

Beck, T., Levine, R. (2004), Stock markets, banks, and growth: panel evidence. Journal of Banking and Finance 28, 423-442.

Beck, T., Levine, R., Loayza, N. (2000b), Finance and the sources of growth. Journal of Financial Economics 58, 261-300.

Bekaert, G., Harvey, C.R., Lundblad, C., Siegel, S. (2007), Global growth opportunities and market integration. Journal of Finance 62, 1081-1137.

Bengoa, M., Sanches-Robles, B. (2003). Foreign direct investment, economic freedom and growth: New evidence from Latin America. European Journal of Political Economy 19, 529-545.

Bernanke, B. S., Gurkaynak, R. S. (2002). Is Growth Exogenous? Taking Mankiw, Romer and Weil Seriously. in NBER Macroeconomics Annual 2001, Volume 16, MIT Press. 
Blalock, G., Gertler, P. (2003), Technology from foreign direct investment and gains through the supply chain. Working paper, Cornell University, Ithaca, N.Y.

Blömstrom, M. (1986), Foreign investment and productivity efficiency: the case of Mexico. Journal of International Economics 15, 97-110.

Blömstrom, M., A. Kokko. (2003). ), The economics of foreign direct investment incentives. NBER Working Paper 9489.

Blömstrom, M., Kokko, A. (1998), Multinational corporations and spillovers, Journal of Economic Surveys $12,247-277$.

Blömstrom, M., Persson, H. (1983), Foreign investment and spillover efficiency in an underdeveloped economy: evidence from the Mexican manufacturing industry. World Development 11, 493-501.

Blömstrom, M., Wolff, E. W. (1994). ), Multinational corporations and productivity convergence in Mexico, in William J. Baumol, Richard R. Nelson, and Edward N. Wolff, eds., Convergence of productivity: Cross-national studies and historical evidence. Oxford: Oxford University Press, 1994, 263-84.

Borensztein, E., de Gregorio, J., Lee, J. W. (1998), How does foreign direct investment affect economic growth?. Journal of international Economics 45, 115-135.

Bottazzi, L., Peri, G. (2003). Innovation and spillovers in regions: Evidence from European patent data. European Economic Review 47, 687-710.

Bottazzi, L., Peri, G. (2005), The international dynamics of R\&D and innovation in the short and in the long run. NBER Working Paper 11524.

Branstetter, L. (2006), Is foreign direct investment a channel of knowledge spillovers? Evidence from Japan's FDI in the United States. Journal of International Economics 68, 325-344.

Carkovic, M., Levine, R. (2005), Does foreign direct investment accelerate economic growth?. U of Minnesota Department of Finance Working Paper. Available at SSRN: http://ssrn.com/abstract=314924 or doi:10.2139/ssrn.314924.

Carlin, W., Mayer, C. (2003), Finance, investment, and growth. Journal of Financial Economics, 69(1), 191-226.

Castellani, D., Zanfei, A. (2006), Multinational firms, innovation and productivity. Edward Elgar, Cheltenham.

Caves, R. (1974), Multinational firms, competition and productivity in the host country. Economica 41, 176193.

Choe, J. (2003), Do foreign direct investment and gross domestic investment promote economic growth?. Review of Development Economics 7, 44-57.

Coe, D., Helpman, E. (1995), International R\&D spillovers. European Economic Review 39, 859-887.

Coe, D., Helpman, E., Hoffmaister, A. W. (2009), International R\&D spillovers and institutions. European Economic Review 53, 723-741.

De Mello, Jr. L.R. (1999), FDI-led growth: evidence from time series and panel data. Oxford Economic Papers 133-151.

Durham, B. (2004), Absorptive capacity and the effects of FDI and equity foreign portfolio investment on economic growth. European Economic Review 48, 285-306.

Edwards, K., Gordon, T. (1984), Characterization of innovations introduced on the US market in 1982. Report prepared for the US Small Business Administration. The Futures Group. Department of commerce, Washington: NTIS.

Engelbrecht, H. J. (1997), International R\&D spillovers, human capital, and productivity in OECD countries: an empirical investigation. European Economic Review 41,1479-1488. 
Findlay, R. (1978), Relative backwardness, direct foreign investment, and the transfer of technology: a simple dynamic model. Quarterly Journal of Economics 92, 1-16.

Globerman, S. (1979), Foreign direct investment and spillover efficiency benefits in Canadian manufacturing industries. Canadian Journal of Economics 12, 42-56.

Görg, H., Greenaway, D. (2004), Much ado about nothing? Do domestic firms really benefit from foreign direct investment?. World Bank Research Observer 19, 171-197.

Griliches, Z. (1990), Patent statistics as economic indicators: a survey. Journal of Economic Literature 28, 1661-1707.

Grossman, G., Helpman, E. (1991), Innovation and Growth in the Global Economy. MIT Press, Cambridge MA.

Hanson, G. H. (2001). Should countries promote foreign direct investment?. G-24 Discussion Paper No. 9. New York: United Nations.

Haskel, J., Pereira, S., Slaughter, M. J. (2006), Does inward foreign direct investment boost the productivity of domestic firms?. The Review of Economics and Statistics 89, 482-496.

Hermes, N., Lensink, R. (2003), Foreign direct investment, financial development and economic growth. Journal of Development Studies 40, 142-63.

Heston A., Summers, R., Aten, B. (2006), Penn World Table Version 6.2. Centre for International Comparisons of Production, Income and Prices at the University of Pennsylvania.

Hsiao, C., Shen, Y. (2003), Foreign direct investment and economic growth: the importance of institutions and urbanization. Economic Development and Cultural Change 51, 883-896.

Ilyina A., Samaniego, R. M. (2008), Technology and finance. IMF Working Paper 08/182. Washington: International Monetary Fund.

Isaksson, A. (2009). The UNIDO World Productivity Database: An Overview. International Productivity Monitor 18, 38-50.

Javorcik, B. (2004). Does foreign direct investment increase the productivity of domestic firms? In search of spillovers through backward linkages. American Economic Review 94(3), 605- 627.

Johnson, D. K. N. (2002), The OECD Technology Concordance (OTC): Patents by industry of manufacture and sector of use. OECD Science, Technology and Industry Working Papers 2002/5, OECD, Directorate for Science, Technology and Industry.

Kaufmann, D., Kraay A., Mastruzzi, M. (2007), Governance matters VI: governance indicators for 19962006. World Bank Policy Research Working Paper No. 4280, World Bank, Washington, D.C.

Keller, W., Yeaple, S. (2009), Multinational enterprises, international trade, and productivity growth: firmlevel evidence from the United States. The Review of Economics and Statistics 91, 821-831.

Kinoshita, Y. (1998), Technology Spillovers through foreign direct investment, CERGE-EI Working Paper Series No. 139. Available at SSRN: http://ssrn.com/abstract=1537049

Kokko, A. (1992), Foreign direct investment, host country characteristics, and spillovers. Doctoral Dissertation, Stockholm School of Economics, Stockholm.

Lall, S. (1980), Vertical interfirm linkages in LDCs: an empirical study. Oxford Bulletin of Economics and Statistics 42, 203-226.

Li, X., Liu, X. (2005), Foreign direct investment and economic growth: an increasingly endogenous relationship. World Development 33, 393-407.

Lin, P., Saggi, K. (2007), Multinational firms, exclusivity, and backward linkages. Journal of International Economics 71, 206-220.

Lipsey, R. E. (2002), Home and host country effects of FDI. NBER Working Paper 9293. 
Mansfield, E., Romeo, A. (1980), Technology transfer to overseas subsidiary by US-based firms. Quarterly Journal of Economics 95, 737-750.

Markusen, J. (1995), The boundaries of multinational enterprises and the theory of international trade. Journal of Economic Perspectives 9, 169-89.

Markusen, J., Venables, A.J. (1999), Foreign Direct investment as a catalyst for industrial development. European Economic Review 43, 335-338.

Narula, R. and Marin, A. (2003), FDI spillovers, absorptive capacities and human capital development: evidence from Argentina. Working Paper, No. 2003-016, Maastricht Economic Research Institute on Innovation and Technology, The Netherlands.

Pavitt, K., Robson, M., Townsend, J. (1987), The size distribution of innovating firms in the UK: 19451984. Journal of Industrial Economics 55, 291-316.

Rajan, R.G., Zingales, L. (1998), Financial dependence and growth. American Economic Review 88, 559586.

Rodriguez-Clare, A. (1996), Multinationals, linkages, and economic development. American Economic Review 86, 851-873.

Sjöholm, F. (1999), Productivity growth in Indonesia: the role of regional characteristics and direct foreign investment. Economic Development and Cultural Change 47, 559-584.

UNCTAD (2009), World Investment Report 2009.

$\mathrm{Xu}$, B. (2000), Multinational enterprises, technology diffusion, and host country productivity growth. Journal of Development Economics 62, 477- 493. 
Table 1

Summary statistics

Summary statistics. For variables definition and sources see Table A in the Appendix.

\begin{tabular}{lcccccc}
\hline Variable & Mean & Median & St. Dev. & Min. & Max. & Obs. \\
\hline Value Added growth rate & 0.181 & 0.200 & 0.673 & -5.824 & 4.562 & 1,453 \\
TFP growth rate & 0.070 & 0.091 & 0.411 & -2.675 & 2.001 & 734 \\
Labor growth rate & 0.079 & -0.004 & 0.381 & -0.478 & 3.197 & 761 \\
Capital growth rate & -0.023 & 0.000 & 0.503 & -4.453 & 3.599 & 1,361 \\
FDI/Capital & 0.141 & 0.018 & 0.558 & 0.000 & 6.798 & 788 \\
FDI/Value Added & $1,065.929$ & 0.029 & $35,761.190$ & 0.000 & $1,200,000.000$ & 1,126 \\
Share of Value Added (\%) & 8.795 & 7.031 & 7.420 & 0.000 & 100.000 & 1,453 \\
Control of Corruption & 1.346 & 1.685 & 1.034 & -0.923 & 2.413 & 1,453 \\
Private Credit & 0.973 & 0.983 & 0.454 & 0.033 & 3.451 & 1,399 \\
Skill Intensity & 0.011 & 0.008 & 0.028 & 0.000 & 1.000 & 1,410 \\
Number of Patents & 190 & 8 & 333 & 0 & 1451 & 1,453 \\
Capital Intensity & 1185.418 & 977.317 & 1052.282 & 5.168 & 13911.120 & 1,066 \\
\hline
\end{tabular}




\section{Table 2}

\section{FDI and value added growth - Baseline specification}

The dependent variable is the growth rate of sector Value Added over five years. For variables definition and sources see Table A in the Appendix. All independent variables are measured at the beginning of the five-year period. Robust standard errors are reported in parentheses. $* * *, * *$ and $*$ indicate statistical significance at the $1 \%, 5 \%$ and $10 \%$ level, respectively.

FDI/Capital $(\log )$

Share of Value Added

Value Added $(\log )$

Year Dummies

Country Dummies

Sector Dummies
(1)

(2)

$\begin{array}{cc}0.031 * * & 0.032 * * \\ (0.015) & (0.014)\end{array}$

(3)

$0.039 *$

(0.022)

0.254

(0.435)

(0.314)

$$
0.017 *
$$

(0.010)

No

No

No

$$
0.040 * * *
$$

(0.012)

Yes

No

No
0.603

(0.403)

$-0.780$

(0.900)

\subsection{4}

(0.024)

$0.024 *$

(0.013)

Yes

Yes

Yes

No
(5)

(4)

$0.054 * *$

(0.023)

$-0.180$

(0.695)

$-0.055$

(0.045)

\begin{tabular}{lccccc}
\hline Observations & 770 & 770 & 770 & 770 & 770 \\
Adjusted $R^{2}$ & 0.006 & 0.114 & 0.172 & 0.195 & 0.269 \\
\hline
\end{tabular}




\section{Table 3}

\section{FDI and value added growth - Additional controls}

The dependent variable is the growth rate of sector Value Added over five years. For variables definition and sources see Table A in the Appendix. All independent variables are measured at the beginning of the five-year period. Robust standard errors are reported in parentheses. $* * *, * *$ and $*$ indicate statistical significance at the $1 \%, 5 \%$ and $10 \%$ level, respectively.

FDI/Capital (log)

Share of Value Added

Value Added (log)

Control of Corruption

Private credit $(\log )$

Skill intensity $(\log )$
(1)

(2)

(3)

$\begin{array}{ccc}0.054 * * & 0.057 * * & 0.037 * \\ (0.023) & (0.023) & (0.022)\end{array}$

$$
-0.180
$$

$-0.211$

0.542

(0.695)

(0.720)

(0.490)

$\begin{array}{ccc}-0.055 & -0.056 & -0.172 * * * \\ (0.045) & (0.045) & (0.055) \\ & & \\ 0.181 * * & 0.102 & 0.132 \\ (0.088) & (0.105) & (0.118)\end{array}$

0.011

0.052

(0.113)

(0.112)

0.086

(0.128)

\begin{tabular}{lccc}
\hline Observations & 770 & 720 & 662 \\
Adjusted $R^{2}$ & 0.269 & 0.273 & 0.297 \\
\hline
\end{tabular}




\section{Table 4}

\section{FDI and value added growth - Labor, capital and technological intensity}

The dependent variable is the growth rate of sector Value Added over five years. For variables definition and sources see Table A in the Appendix. Labor intensive sectors are those with a capital to labor ratio below the sample median; capital intensive sectors are those with a ratio above the sample median. Low-, Middle- and High-tech sectors are defined according to the total number of patents granted to each sector by the US patent office to inventors from all over the world. All independent variables are measured at the beginning of the five-year period. Robust standard errors are reported in parentheses. $* * *, * *$ and $*$ indicate statistical significance at the $1 \%, 5 \%$ and $10 \%$ level, respectively.

\begin{tabular}{lccccc}
\hline & $\begin{array}{c}(1) \\
\text { Labor } \\
\text { intensive }\end{array}$ & $\begin{array}{c}(2) \\
\text { Capital } \\
\text { intensive }\end{array}$ & $\begin{array}{c}(3) \\
\text { Low-tech }\end{array}$ & $\begin{array}{c}(4) \\
\text { Middle-tech }\end{array}$ & $\begin{array}{c}\text { High-tech } \\
\text { FDI/Capital (log) }\end{array}$ \\
& 0.045 & $0.077 * *$ & 0.023 & $0.101^{* *}$ & $0.059^{*}$ \\
& $(0.042)$ & $(0.032)$ & $(0.045)$ & $(0.049)$ & $(0.033)$ \\
Share of Value Added & 0.173 & -0.014 & $1.071 * * *$ & $5.091 * * *$ & -1.127 \\
& $(1.088)$ & $(0.711)$ & $(0.382)$ & $(1.498)$ & $(1.118)$ \\
Value Added (log) & -0.093 & $-0.079 *$ & $-0.108 * *$ & $-0.825 * * *$ & $-0.094 * *$ \\
& $(0.115)$ & $(0.043)$ & $(0.050)$ & $(0.178)$ & $(0.047)$ \\
\hline Observations & 293 & 477 & 312 & 188 & 187 \\
Adjusted $R^{2}$ & 0.364 & 0.320 & 0.285 & 0.565 & 0.453 \\
\hline
\end{tabular}




\section{Table 5}

\section{FDI and TFP, labor and capital growth}

The dependent variables are the growth rate of Total Factor Productivity (Panel 1), of the number of employees (Panel 2) and of Total capital (Panel 3) over five years. For variables definition and sources see Table A in the Appendix. All independent variables are measured at the beginning of the five-year period. Robust standard errors are reported in parentheses. $* * *, * *$ and $*$ indicate statistical significance at the $1 \%, 5 \%$ and $10 \%$ level, respectively.

(1)

(2)

(3)

TFP growth Labor growth Capital growth

FDI/Capital (log)

$\begin{array}{ccc}0.046 * * * & 0.019 & 0.047 * * * \\ (0.012) & (0.019) & (0.011)\end{array}$

Share of Value Added

$\begin{array}{ccc}0.575 * * & 0.598 * * * & 0.338 \\ (0.232) & (0.204) & (0.280)\end{array}$

TFP level (log)

$-0.540 * * *$

(0.054)

Number of employees (log)

Total capital (log)

\begin{tabular}{lccc}
\hline Observations & 766 & 776 & 844 \\
Adjusted $R^{2}$ & 0.487 & 0.286 & 0.568 \\
\hline
\end{tabular}




\section{Table 6}

\section{FDI and growth - GMM estimates}

The dependent variables are the growth rate of Value added (Panel 1), Total Factor Productivity (Panel 2), the number of employees (Panel 3) and Total capital (Panel 4) over five years. Estimates are conducted using GMM. For variables definition and sources see Table A in the Appendix. All independent variables are measured at the beginning of the five-year period. Robust standard errors are reported in parentheses. $* * *, * *$ and $*$ indicate statistical significance at the $1 \%, 5 \%$ and $10 \%$ level, respectively.

(1)

Value added growth

FDI/Capital (log)

Share of Value Added

0.127

(0.136)

$-0.025$

$(0.019)$

TFP level $(\log )$

$0.322 * * *$

$(0.021)$

Value Added (log)

$-0.698 * * *$

(0.035)
(4)

(3)

TFP growth Labor growth Capital growth

TFP growth Labor growth Capital growth

$\begin{array}{ccc}0.353^{* * *} * & -0.019 * * & 0.066 * * * \\ (0.018) & (0.008) & (0.007)\end{array}$

$1.113 * * *$

$0.729 * * *$

0.000

(0.095)

(0.085)

$(0.000)$

\footnotetext{
Number of employees $(\log )$
}

Total capital $(\log )$ 


\section{Table 7}

\section{FDI and value added growth - Robustness checks}

In Panels 1, 3 and 4 the dependent variable is the growth rate of sector Value Added over five years; in Panels 2 and 5 it is the growth rate of sector Value Added over ten years. In Panels 1 and 4 only non-overlapping periods of five years are considered. For variables definition and sources see Table A in the Appendix. In Panels 1, 3 and 4, independent variables are measured at the beginning of the five-year period; in Panels 2 and 5 independent variables are measured at the beginning of the ten-year period. Robust standard errors are reported in parentheses. $* * * * *$ and $*$ indicate statistical significance at the $1 \%, 5 \%$ and $10 \%$ level, respectively.

(1)

(2)

(3)

Nonoverlapping 5years

\section{Overlapping 10 years}

$$
\begin{gathered}
0.076 * * * \\
(0.032)
\end{gathered}
$$

FDI/Value added $(\log )$

Share of Value Added

Value Added (log)

$$
-0.327
$$

$0.040^{*}$

$(0.023)$

$$
\begin{gathered}
0.093 * * * \\
(0.020)
\end{gathered}
$$

$0.105 * *$

(0.041)

$0.242 * * *$

FDI/Value

(5)

Added, non overlapping 5 years
FDI/ Value Added, overlapping 10 years

$\begin{array}{llllcc}\text { Share of Value Added } & -0.327 & -0.276 & -0.289 & 0.873 & 1.237 \\ & (0.551) & (1.104) & (0.600) & (0.836) & (1.118) \\ \text { Value Added }(\log ) & 0.040^{*} & -0.003 & -0.021 & -0.175^{* *} & -0.106 \\ & (0.023) & (0.110) & (0.057) & (0.085) & (0.111)\end{array}$

\begin{tabular}{lccccc}
\hline Observations & 194 & 286 & 1,453 & 345 & 785 \\
Adjusted $R^{2}$ & 0.082 & 0.393 & 0.340 & 0.301 & 0.501 \\
\hline
\end{tabular}




\section{Table 8}

FDI and value added growth - The case of the food processing industry

The dependent variables are the growth rate of Value Added (Panel 1), of Total Factor Productivity (Panel 2), of the number of employees (Panel 3) and of Total capital (Panel 4) over five years. Food dummy is a dummy that takes the value of one for FDIs in the food manufacturing sector. For variables definition and sources see Table A in the appendix. All independent variables are measured at the beginning of the five-year period. Robust standard errors are reported in parentheses. ***, ** and * indicate statistical significance at the $1 \%, 5 \%$ and $10 \%$ level, respectively.

(1) (2) (3) (4)

VA growth TFP growth Labor growth Capital growth

$\begin{array}{lcccc}\text { FDI/Capital }(\log ) & 0.054 * * & 0.046^{* * *} & 0.018 & 0.047 * * * \\ & (0.023) & (0.012) & (0.019) & (0.011) \\ \text { FDI/Capital }(\log ) * \text { Food dummy } & -0.013 & 0.010 & 0.027 & 0.146^{* * * *} \\ & (0.043) & (0.023) & (0.038) & (0.032) \\ \text { Share of Value Added } & -0.179 & 0.576^{* *} & 0.599 * * * & 0.287 \\ & (0.695) & (0.232) & (0.204) & (0.257)\end{array}$

Value Added $(\log ) \quad-0.055$

$(0.045)$

TFP level $(\log )$

Number of employees $(\log )$

Total capital $(\log )$

\begin{tabular}{lcccc}
\hline Observations & 770 & 766 & 776 & 844 \\
Adjusted $R^{2}$ & 0.268 & 0.486 & 0.286 & 0.588 \\
\hline
\end{tabular}




\section{Table A}

\section{Variables description and sources}

Description and sources of all the variables used in the empirical analysis grouped in three categories: country-level variables, industry-level variables and variables calculated from the original data.

\begin{tabular}{ll}
\hline \hline Definition & Description and Source
\end{tabular}

Country-level variables:

Control of Corruption (log)

Private Credit $(\log )$

Skill Intensity

\section{Industry-level variables:}

Value Added $(\log )$

Output

Number of Employees

Investment

FDI

Number of patents $(\log )$
Perceptions of the extent to which public power is exercised for private gain, including both petty and grand forms of corruption, as well as "capture" of the state by elites and private interests. This governance indicators is measured in units ranging from about -2.5 to 2.5 , with higher values corresponding to better governance outcomes.

Source: Kaufmann et al. (2007).

http://www.worldbank.org/wbi/governance

Value of private credit issued by deposit money banks and other financial institutions to the private sector divided by GDP. It excludes the credit issued to governments and public agencies and the credit issued by the central bank.

Source: World Bank Financial Structure Database

http://www.worldbank.org/research/projects/finstructure/database.htm

High skill workers as a proportion of total employment.

Source: ISCO88

http://laborsta.ilo.org

Value of census output less the value of census input.

Source: UNIDO Industrial Statistics Database - Indstat 4 2008, Revisions 2 and 3

Output from activities of an industrial nature.

Source: UNIDO Industrial Statistics Database - Indstat 4 2008, Revisions 2 and 3

Total number of persons who worked in or for the establishment during the reference year.

Source: UNIDO Industrial Statistics Database - Indstat 4 2008, Revisions 2 and 3

Value of purchases and own account construction of fixed assets during the reference year less the value of corresponding sales.

Source: UNIDO Industrial Statistics Database - Indstat 4 2008, Revisions 2 and 3

Net stocks of investment needed to acquire a lasting management interest in an enterprise operating in an economy other than that of the investor.

Source: UNCTAD

Annual number of US granted utility patents classified according to the US Patent Classification (USPC).

Source: http://www.nber.org/patents/ 
Table A (continued)

\begin{tabular}{ll}
\hline \hline Definition & Description \\
\hline \hline
\end{tabular}

Variables calculated from original data:

Value Added growth rate

Difference in natural logarithms of industry value-added for five-year periods.

Share of Value Added

Share of value added of industry $i$ in country $c$ to the country's total value added.

Total Capital

Capital stock at industry level calculated with the inventory method by applying depreciation rates by sector from Ilyna and Samaniego (2008).

FDI/Capital $(\log )$

Foreign direct investment divided by the capital stock.

FDI/Value Added (log)

Foreign direct investment divided by the value added.

TFP $(\log )$

Total factor productivity at sector level calculated as: TFP $=y /\left(k^{\alpha}\right)$ where $y$ is the level of per-capita output and $k$ is the level of per-capita capital. TFP was estimated from a constant returns to scale Cobb-Douglas production function with the capital share set at $1 / 3$ and labour share at $2 / 3$.

TFP growth rate

Difference in natural logarithms of industry total factor productivity for five-year periods.

Capital growth rate

Difference in natural logarithms of industry capital for five-year periods.

Labor growth rate

Difference in natural logarithms of industry labor for five-year periods. 


\section{Table B}

Correspondence between the classification of sectors adopted in the paper and the classification defined by UNCTAD

\begin{tabular}{|c|c|}
\hline Sector & Sector UNCTAD \\
\hline Food products & $\begin{array}{l}\text { Production, processing and preserving of meat and meat products } \\
\text { Processing and preserving of fish and fish products } \\
\text { Processing and preserving of fruit and vegetables } \\
\text { Manufacture of dairy products } \\
\text { Manufacture of grain mill products } \\
\text { Manufacture of prepared animal feeds } \\
\text { Manufacture of bakery products } \\
\text { Manufacture of sugar } \\
\text { Manufacture of other food products n.e.c. } \\
\text { Unspecified food, beverages and tobacco } \\
\text { Unspecified beverages } \\
\text { Unspecified other food products } \\
\text { Unspecified food products and beverages } \\
\text { Unspecified meat, fish, fruit, vegetables, oils and fats } \\
\text { Tobacco products }\end{array}$ \\
\hline Textile, Leather and Apparel & $\begin{array}{l}\text { Preparation and spinning of textile fibers / weaving of textiles } \\
\text { Finishing of textiles } \\
\text { Manufacture of wearing apparel, except fur apparel } \\
\text { Manufacture of footwear } \\
\text { Unspecified wearing apparel } \\
\text { Unspecified tanning and dressing of leather } \\
\text { Unspecified textiles } \\
\text { Unspecified leather and leather products } \\
\text { Unspecified textiles, clothing and leather }\end{array}$ \\
\hline Wood Products and Furniture & $\begin{array}{l}\text { Sawmilling and planing of wood } \\
\text { Manufacture of other products of wood / manufacture of articles of cork, straw and } \\
\text { plaiting materials } \\
\text { Manufacture of furniture } \\
\text { Unspecified wood and wood products } \\
\text { Unspecified wood products }\end{array}$ \\
\hline Plastic Products and Chemicals & $\begin{array}{l}\text { Manufacture of refined petroleum products } \\
\text { Manufacture of basic chemicals, except fertilizers and nitrogen compounds } \\
\text { Manufacture of fertilizers and nitrogen compounds } \\
\text { Manufacture of plastics in primary forms and of synthetic rubber } \\
\text { Manufactures of pesticides and other agro-chemical products } \\
\text { Manufacture of paints, varnishes and similar coatings, printing ink and mastics } \\
\text { Manufacture of pharmaceuticals, medicinal chemicals and botanical products } \\
\text { Manufacture of soap and detergents, cleaning and polishing preparations, perfumes } \\
\text { and toilet preparations } \\
\text { Manufacture of other chemical products n.e.c. } \\
\text { Manufacture of plastic products } \\
\text { Unspecified rubber and plastic products } \\
\text { Unspecified chemicals and chemical products } \\
\text { Unspecified coke, refined petroleum products and nuclear fuel } \\
\text { Unspecified rubber products } \\
\text { Unspecified basic chemicals } \\
\text { Unspecified other chemical products }\end{array}$ \\
\hline Glass and Non-Metallic Products & $\begin{array}{l}\text { Manufacture of glass and glass products } \\
\text { Manufacture of refractory ceramic products } \\
\text { Manufacture of cement, lime and plaster }\end{array}$ \\
\hline
\end{tabular}


Machinery

Electric Machinery

Machinery and Equipment

Printing and Publishing

Transport Equipment

Metal Products
Manufacture of articles of concrete, cement and plaster

Cutting, shaping and finishing of stone

Manufacture of other non-metallic mineral products n.e.c.

Unspecified non-metallic mineral products

Unspecified non-metallic mineral products n.e.c.

Unspecified electrical machinery

Unspecified electrical and electronic equipment

Office, accounting and computing machinery

Manufacture of electric motors, generators and transformers

Manufacture of electronic valves and tubes and other electronic components

Manufacture of television and radio transmitters and apparatus for line telephony and line telegraphy

Manufacture of television and radio receivers, sound or video recording or reproducing apparatus, and associated goods

Unspecified radio, tv and communications equipment

Manufacture of engines and turbines, except aircraft, vehicle and cycle engines

Manufacture of pumps, compressors, taps and valves

Manufacture of other general purpose machinery

Manufacture of agricultural and forestry machinery

Manufacture of machine-tools

Manufacture of machinery for mining, quarrying and construction

Manufacture of machinery for food, beverage and tobacco processing

Manufacture of weapons and ammunition

Manufacture of other special purpose machinery

Manufacture of domestic appliances n.e.c.

Manufacture of electric lamps and lighting equipment

Manufacture of other electrical equipment n.e.c.

Manufacture of medical surgical equipment and orthopaedic appliances

Manufacture of instruments and appliances for measuring, checking, testing and navigating and other purposes, except industrial process control equipment

Manufacture of optical instruments and photographic equipment

Manufacture of watches and clocks

Unspecified machinery and equipment

Unspecified special purpose machinery

Unspecified general purpose machinery

Unspecified precision instruments

Publishing of newspapers, journals and periodicals

Printing

Unspecified publishing

Unspecified printing

Unspecified publishing, printing and reproduction of recorded media

Manufacture of motor vehicles

Manufacture of bodies for motor vehicles / manufacture of trailers and semitrailers

Manufacture of parts and accessories for motor vehicles and their engines

Manufacture of railway and tramway locomotives and rolling stock

Manufacture of aircraft and spacecraft

Unspecified motor vehicles, trailers and semi-trailers

Unspecified building and repairing of ships and boats

Unspecified transport equipment n.e.c.

Unspecified other transport equipment

Unspecified motor vehicles and other transport equipment

Manufacture of basic iron and steel

Manufacture of basic precious and non-ferrous metals

Casting of iron and steel 


Casting of non-ferrous metals
Manufacture of structural metal products
Manufacture of tanks, reservoirs and containers of metal
Forging, pressing, stamping and roll-forming of metal; powder metallurgy
treatment and coating of metals / general mechanical engineering on a fee or
contract basis
Manufacture of cutlery, hand tools and general hardware
Manufacture of other fabricated metal products n.e.c
Unspecified metal and metal products
Unspecified structural metal products
Unspecified casting of metals
Unspecified fabricated metal products
Unspecified other fabricated metals products
Unspecified basic metals
Manufacture of pulp, paper and paperboard
Manufacture of corrugated paper and paperboard and of containers of paper and
paperboard
Manufacture of other articles of paper and paperboard
Unspecified paper and paper products
Manufacture of jewellery and related articles
Unspecified manufacturing n.e.c.
Unspecified other manufacturing
Production, collection and distribution of electricity
Manufacture of gas / distribution of gaseous fuels through mains
Collection, purification and distribution of water
Unspecified electricity, gas and water
Other Industries




\section{Table C}

Correspondence between the classification of sectors adopted in the paper and the classification defined by UNIDO.

\begin{tabular}{|c|c|}
\hline Sector & Sector UNIDO \\
\hline Food products & $\begin{array}{l}\text { Processed meat,fish,fruit,vegetables,fats } \\
\text { Processing/preserving of meat } \\
\text { Processing/preserving of fish } \\
\text { Processing/preserving of fruit \& vegetables } \\
\text { Vegetable and animal oils and fats } \\
\text { Dairy products } \\
\text { Grain mill products; starches; animal feeds } \\
\text { Grain mill products } \\
\text { Starches and starch products } \\
\text { Prepared animal feeds } \\
\text { Other food products } \\
\text { Bakery products } \\
\text { Sugar } \\
\text { Cocoa, chocolate and sugar confectionery } \\
\text { Macaroni, noodles \& similar products } \\
\text { Other food products n.e.c. } \\
\text { Beverages } \\
\text { Distilling, rectifying \& blending of spirits } \\
\text { Wines } \\
\text { Malt liquors and malt } \\
\text { Soft drinks; mineral waters } \\
\text { Tobacco products }\end{array}$ \\
\hline Textile, Leather and Apparel & $\begin{array}{l}\text { Spinning, weaving and finishing of textiles } \\
\text { Textile fibre preparation; textile weaving } \\
\text { Finishing of textiles } \\
\text { Other textiles } \\
\text { Made-up textile articles, except apparel } \\
\text { Carpets and rugs } \\
\text { Cordage, rope, twine and netting } \\
\text { Other textiles n.e.c. } \\
\text { Knitted and crocheted fabrics and articles } \\
\text { Wearing apparel, except fur apparel } \\
\text { Dressing \& dyeing of fur; processing of fur } \\
\text { Tanning, dressing and processing of leather } \\
\text { Tanning and dressing of leather } \\
\text { Luggage, handbags, etc.; saddlery \& harness } \\
\text { Footwear }\end{array}$ \\
\hline Wood Products and Furniture & $\begin{array}{l}\text { Sawmilling and planing of wood } \\
\text { Products of wood, cork, straw, etc. } \\
\text { Veneer sheets, plywood, particle board, etc. } \\
\text { Builders' carpentry and joinery } \\
\text { Wooden containers } \\
\text { Other wood products; articles of cork/straw } \\
\text { Furniture }\end{array}$ \\
\hline Plastic Products and Chemicals & $\begin{array}{l}\text { Coke oven products } \\
\text { Refined petroleum products } \\
\text { Processing of nuclear fuel } \\
\text { Basic chemicals } \\
\text { Basic chemicals, except fertilizers } \\
\text { Fertilizers and nitrogen compounds }\end{array}$ \\
\hline
\end{tabular}


Glass and Non-Metallic Products

Machinery
Electric Machinery

Machinery and Equipment

Printing and Publishing
Plastics in primary forms; synthetic rubber

Other chemicals

Pesticides and other agro-chemical products

Paints, varnishes, printing ink and mastics

Pharmaceuticals, medicinal chemicals, etc.

Soap, cleaning \& cosmetic preparations

Other chemical products n.e.c.

Man-made fibres

Rubber products

Rubber tyres and tubes

Other rubber products

Plastic products

Glass and glass products

Non-metallic mineral products n.e.c.

Pottery, china and earthenware

Refractory ceramic products

Struct.non-refractory clay; ceramic products

Cement, lime and plaster

Articles of concrete, cement and plaster

Cutting, shaping \& finishing of stone

Other non-metallic mineral products n.e.c.

Office, accounting and computing machinery

Electric motors, generators and transformers

Electronic valves, tubes, etc.

TV/radio transmitters; line comm. apparatus

$\mathrm{TV}$ and radio receivers and associated goods

General purpose machinery

Engines \& turbines (not for transport equipment)

Pumps, compressors, taps and valves

Bearings, gears, gearing \& driving elements

Ovens, furnaces and furnace burners

Lifting and handling equipment

Other general purpose machinery

Special purpose machinery

Agricultural and forestry machinery

Machine tools

Machinery for metallurgy

Machinery for mining \& construction

Food/beverage/tobacco processing machinery

Machinery for textile, apparel and leather

Weapons and ammunition

Other special purpose machinery

Domestic appliances n.e.c.

Insulated wire and cable

Accumulators, primary cells and batteries

Lighting equipment and electric lamps

Other electrical equipment n.e.c.

Medical, measuring, testing appliances, etc.

Medical, surgical and orthopaedic equipment

Measuring/testing/navigating appliances,etc.

Industrial process control equipment

Optical instruments \& photographic equipment

Watches and clocks

Publishing 
Transport Equipment

Metal Products

Paper and Paper Products

Other Industries

Electricity, Gas and Water
Publishing of books and other publications

Publishing of newspapers, journals, etc.

Publishing of recorded media

Other publishing

Printing and related service activities

Printing

Service activities related to printing

Reproduction of recorded media

Motor vehicles

Automobile bodies, trailers \& semi-trailers

Parts/accessories for automobiles

Building and repairing of ships and boats

Building and repairing of ships

Building/repairing of pleasure/sport. boats

Railway/tramway locomotives \& rolling stock

Aircraft and spacecraft

Transport equipment n.e.c.

Motorcycles

Bicycles and invalid carriages

Other transport equipment n.e.c.

Basic iron and steel

Basic precious and non-ferrous metals

Casting of metals

Casting of iron and steel

Casting of non-ferrous metals

Struct.metal products;tanks;steam generators

Structural metal products

Tanks, reservoirs and containers of metal

Steam generators, except central heating hot water boilers

Other metal products; metal working services

Metal forging/pressing/stamping/roll-forming

Treatment \& coating of metals

Cutlery, hand tools and general hardware

Other fabricated metal products n.e.c.

Recycling of metal waste and scrap

Recycling of non-metal waste and scrap

Paper and paper products

Pulp, paper and paperboard

Corrugated paper and paperboard

Other articles of paper and paperboard

Manufacturing n.e.c.

Jewellery and related articles

Musical instruments

Sports goods

Games and toys

Other manufacturing n.e.c.

Electricity distribution \& control apparatus 